Volume:8 Issue:1

https://dx.doi.org/10.19128/turje.454138
Turkish Journal of Education

Research Article

\title{
Resilience among Syrian university students in Turkey
}

\author{
Özgür Osman Demir
}

Hasan Kalyoncu University, Faculty of Education, Gaziantep, Turkey, demirozgur02@gmail.com ORCID: https://orcid.org/ 0000-0002-5073-151X

\section{Ramin Aliyev}

Hasan Kalyoncu University, Faculty of Education, Gaziantep, Turkey, aliyevus@ gmail.com ORCID: https://orcid.org/ 0000-0003-1983-6505

\begin{abstract}
The purpose of this research is to deeply examine the resilience in war victim immigrants based on risk and protective factors. The sample of the research, which is structured as a phenomenological study, a type of qualitative research, constitute of 5 women, 5 men and 10 university students. A semi-structured Immigrant University Students Resilience Interview Form, created by the researchers, was used as a data collection tool. According to the results, while the risk factors of the participants were mainly societal, the protective factors were mainly individual. Additionally, the risk factors are distrust in others, anger management, pessimism, financial difficulty, media effect, witnessing to death, interruption of education, social prejudice and unsupportive, new settlement, language problem, change of living space, death of family member, living apart to family. The protective factors are; social contribution, career goals, patience, self-confidence, desire for learning, grit, spirituality, financial situation, host society support, immigrant support, family members support. Furthermore, it was found that the percentage of the participants who consider themselves as happy and standing individuals which is a sign of resilience was high.
\end{abstract}

Keywords: $\quad$ Resilience, Immigrants, Risk factors, Protective factors

\section{Türkiye'deki Suriyeli üniversite öğrencilerinde yılmazlık}

ÖZ $\mathrm{Bu}$ araştırmanın amacı savaş mağduru göçmenlerde risk ve koruyucu faktörler temelinde yılmazlık kaynaklarını derinlemesine incelemektir. Nitel araştırmaların bir türü olan "olgubilim (fenomenoloji) çalışması" olarak yapılan araştırmanın örneklemini savaştan dolayı Türkiye'ye göç etmek zorunda kalmış 5 kadın, 5 erkek 10 üniversite eğitimi gören öğrenci oluşturmuştur. Veri toplama aracı olarak araştırmacılar tarafından geliștirilen yarı yapılandırılmıș Göçmen Üniversite Öğrencilerinde Yılmazlık Görüşme Formu kullanılmıştır. Araştırma sonuçlarına göre risk farktörleri daha çok sosyal kaynaklı iken, bireysel faktörler bireysel kaynaklıdır. Ayrıca beliritlen risk faktörleri şu şekildedir: Başkalarına güvensizlik, öfke kontrolü, olumsuz bakış açısı, finansal zorluklar, medya etkisi, ölüme şahit olmak, eğitimin sekteye uğraması, sosyal önyarg1 ve dişlanma, yeni yerleşim yeri ile ilgili sorunlar, dil problemi, yaşam alanı değişimi, aile üyelerinden birinin ölümü ve aile üyelerinden ayrı yaşamak. Koruyucu faktörler ise şu şekildedir: Sosyal destek, kariyer amaçlılığı, sabır, özgüven, öğrenmeye istekli olmak, azim, maneviyat, finansal destek, ev sahibi topum desteği, göçmen desteği ve aile üyelerinin desteği. Bunun yanında katılımcıların yılmazlığın bir göstergesi olarak, kendilerini mutlu ve ayakta kalmış/güçlü olarak nitelendirme yoğunluklarının fazla olduğu belirlenmiştir.

Anahtar Yllmazlık, Göçmenler, Risk faktörleri, Koruyucu faktörler

Kelimele

Cite This Demir, Ö.O. \& Aliyev, R., (2019). Resilience among Syrian university students in Turkey, Article: Turkish Journal of Education. 8(1), 33-51. https://dx.doi.org/10.19128/turje.454138 


\section{INTRODUCTION}

Positive psychology has investigated the lives of 'normal people' instead of human figurines in the pathological structure studied up to now. Positive psychology, aiming to reveal the forces that exist within people, is seeking to make the sources of environmental support recognized by emphasizing the strengths of individuals (Seligman \& Csikszentmihalyi, 2014). In this sense, there are many issues that positive psychology has emphasized. Resilience is one of these issues.

Although there is no clear unanimity in definitions and processes, there are many common points about the concept of resilience in research. Considering that, resilience can be described as having developable characteristics which make individuals remain standing, overcome difficulties and show a better development than expected despite the negative and stressful life experiences (Gürgan, 2006). Three important conditions are necessary for resilience processes. These are risk factors, protective factors and positive results. There is no definite criteria that can be used for any variable to be identified as risk factor or protective factor. Therefore, individual, familial and social variables are taken into consideration when identifying the possible risk and protective factors (Gordon \& Song, 1994). Risk factors increase the likelihood of a negative situation or cause a problem to continue (Terzi, 2008). Low birthrate, domestic violence, low socio-economic level, divorce, strict or inattentive parenting, natural disasters, terrorism, cognitive difficulties, poor nutrition, poverty, homelessness and displacing the family are all considered as risk factors (Masten, 2014). Protective factors prevent the negative consequences of risk factors (Rutter, 1999), reduce the effects of risk factors and serve to meet the individual's developmental needs (Sipahioğlu, 2008). Concepts such as positive interactions within the family, social support, having self-confidence, hope, having a particular interest or hobby, mentoring, familial support and events that can be considered as milestones constitute protective factors (Masten \& Reed, 2002; Öğülmüş, 2001). Risk factors and protective factors have a dynamic structure. A situation that is a risk for a person can be protective factor for someone else. Moreover, a situation which has been a risk factor for the same person can become a protective factor (Kiernan \& Mensah, 2011).

Under normal circumstances, the usage of the term "refugee" seems to be descriptively appropriate for the individuals who come from Syria. However, the national and international obligations that the term brings are such that the countries, like Syria, that face the problem of migration due to extraordinary problems would not want to take responsibility. Thus, the term 'guest' is often used especially for the Syrians who came to Turkey (Gürcanl1, 2012). Accordingly, the lack of a general definition of the term "immigrant" within the international law framework creates further confusion in the literature. This confusion especially manifests itself in the academic studies in Turkey. When the studies are examined, it is seen that the definitions of 'asylum seeker', 'refugee' and 'migrant' are made for the people coming from Syria (Ilbay, 2017; Keklik, 2016; Unat, 2015). In this regard, the concept which is referred as 'refugee' for individuals, who escaped from the Syrian war and took shelter in other countries, is expressed as 'immigrant' within the scope of this study.

UNHCR (United Nations High Commissioner for Refugees) and many researchers have shown that immigrants who have been forced to migrate due to war go through different experiences than the immigrants who have migrated due to other reasons. Most war victim immigrants are ten times more exposed to post-traumatic stress disorder than the people in the community because of the long-term armed conflicts, violence, loss of family members or mass death (Fazel, Wheeler, \& Danesh, 2005; Wenzel, Kastrup, \& Eisenman, 2007). Yakushko and Morgan (2012) classify the problems that immigrants experience as follows: difficulties in orientating into a new culture, challenges with the language, relational conflicts (domestic violence, intergenerational conflicts), economic pressures, discrimination, loss of social connections and social status. Although immigrants have many risk factors, their individual, familial and social support systems enable them to pass these risks without being affected or with a slight impact with cultural codes (Mawani, 2014; Pickren, 2014). For immigrants, 
language is the most important structure in which the culture is protected. Some studies show that immigrant families encourage their children to speak their own language at home. Religious ceremonies and rituals are also protective factors of cultural protection for immigrants (Inman, Howard, Beaumont, $\&$ Walker, 2007). Besides, immigrants tend to gather in certain neighborhoods in countries where they are settled. This is important for the protection of their mental health (Mawani, 2014).

Yakushko and Morgan (2012), emphasized the lack of study regarding the immigration resilience processes and underlined the necessity of conducting qualitative studies for future research on this subject in terms of showing sensitivity towards the cultural values. The experiences of the immigrants, who have come from diverse backgrounds and have gone to different host countries are quite varied. Therefore, in-depth qualitative analyses will contribute to create a clearer picture of the process. This research has great importance since it is the first resilience study on the immigrants in Turkey. The results of the research also carry another importance since it brings a better understanding of the immigrant's lives and increase the social integration by improving the empathy in society. Based on the current literature, in order to bridge the research gap, the present study was intended to deeply examine the sources of resilience in Syrian immigrant university students based on risk and protective factors.

\section{METHODOLOGY}

\section{Model}

This research is designed as a phenomenological study, a type of qualitative research, in order to examine the resilience process of immigrants in detail. Phenomenological study aims to deeply investigate the phenomena that are not entirely unfamiliar to us, but we cannot fully understand (Fraenkel, Wallen, \& Hyun, 2012; Yıldırım \& Şimşek, 2013).

\section{Sample}

The research sample consists of immigrant university students, between the ages of 21-28, who migrated to Turkey because of the war in their country. The size of the sample in qualitative research is related to the data reaching the saturation point. When the obtained concepts begin to repeat themselves, it can be decided that the data has reached the saturation point (Yıldırım \& Şimşek, 2013). In this context, the data reached the saturation point with 5 females and 5 male individuals who participated in the study, and these participants formed the sample.

The individuals who involved in the research have been residing in Turkey between 2.5 and 5 years since the migration. Individuals who participated in the research have been forced to migrate to Turkey from Aleppo, Baghdad, Latakia and Damascus because of the war.

Within the scope of the study, the sample was determined by the 'criterion sampling' method. Criteria sampling is a sampling method in which a unit is selected if it meets certain criteria in cases where the observation unit is composed of individuals, events or objects with specific qualities (Büyüköztürk, Çakmak, Akgün, Karadeniz, \& Demirel, 2016). In this context, the criteria for participating in the research are as follows: being emigrated from Syria to Turkey, to be a university student, have been living in Turkey for at least one year. 
Within the scope of the research, 'interview' was used for collecting data. Interview is a method in which a number of questions are addressed to the interviewee (Christensen, Johnson, \& Turner 2014). The interviews were performed by using the 'Immigrant University Students Resilience Interview Form', developed by the researchers. The interviews were conducted in February-March 2017. Detailed information related to the interview form is given below.

\section{Data Collection Tools}

Interview form of the resilience among immigrant university students: It is an interview form consisting of open ended questions to determine the processes of resilience that the individuals experience in host countries they migrated to. During the preparation of the interview form, the resilience and migration literature was reviewed, and the scale items in the area were examined and questions were prepared in a manner appropriate to the nature of the qualitative research. The questions were finalized through a pilot study and three revisions with the contributions of two field experts (Professor and Assistant Professor) and an Assessment and Evaluation specialist (Professor). The interview form providing detailed information on the risk factors, protective factors and positive results that have a role in the resilience process of immigrants consists of 10 questions. Two sample questions are as follows: "Can you tell us about the three important factors that make you strong and make you feel good in this process?", "Have you encountered an individual, familial or social obstacle that changed your life in this process? Can you explain them in detail? Can you give examples?" (Demir, 2017).

\section{Process}

The individual interviews conducted as a part of the research were performed in a room where physical conditions were appropriate. Water and napkin were available for the participants during the interviews. Interviews were paused when the participants started to cry and continued as they felt better. While the 7 of the interviews were conducted individually with the participants, there was a translator in 3 of them due to language difficulties of the participants. Translation languages were Turkish and Arabic. The errors caused by translation tried to be minimized by having the same translator in 3 interviews and providing the translator detailed information about the subject before the interview.

In qualitative research, reliability requires detailed explanations of the process by the researcher and consistency with different researchers (Gibbs, 2007). Moreover, in order to increase credibility in qualitative research, it is necessary to have the reliability of the researcher and the theoretical basis of the research (Çelik, 2014). In the scope of the research, transmitting the process and the findings clearly, receiving feedback by different experts who were following the process and evaluating the findings in the light of literature are the factors that increase the reliability. In addition, 'participant confirmation' was taken after each interview to prevent the inclusion of false or incomplete information in the research.

Validity of qualitative research is a status in which the authenticity of the documents can be proven by the researcher (Gibbs, 2007). Researcher's eluding from his prejudice, the research having descriptive validity, checking the data and coding with more than one researcher and the direct citation of the participants are the conditions which increase validity (Christensen et al., 2014). Within the scope of the research, the practices were carried out with the principle of impartiality and everything told by the participants was recorded and examined.

In the data coding stage, the opinions of two course experts in the field were taken and the concordance between the coders was observed. Besides, the words used frequently by the participants were referred in the findings section. These conditions increase the validity of the research. The meanings of the codes in the findings section are given in Table 1. 
Table 1.

The meanings of the codes

\begin{tabular}{|c|c|c|c|}
\hline Protective Factors & & Risk Factors & \\
\hline $\begin{array}{l}\text { Social } \\
\text { contribution }\end{array}$ & $\begin{array}{l}\text { Willingness to contribute to the } \\
\text { society they live in. }\end{array}$ & Distrust in others & $\begin{array}{l}\text { The feeling of insecurity to all people } \\
\text { due to the experienced events. }\end{array}$ \\
\hline Career goals & $\begin{array}{l}\text { Having goals related to future } \\
\text { professional life. }\end{array}$ & Anger management & $\begin{array}{l}\text { Inability to control anger in most } \\
\text { situations in daily life. }\end{array}$ \\
\hline Patience & Staying calm despite the negativity. & Pessimism & $\begin{array}{l}\text { Having a negative attitude towards } \\
\text { life. }\end{array}$ \\
\hline Self-confidence & Feeling adequate. & Financial difficulty & Any financial difficulties experienced. \\
\hline $\begin{array}{l}\text { Desire for } \\
\text { learning }\end{array}$ & Indulging in learning something new. & Media effect & $\begin{array}{l}\text { Reading or seeing the news about the } \\
\text { region in different media, even if you } \\
\text { are away from home. }\end{array}$ \\
\hline Grit & $\begin{array}{l}\text { Not giving up despite negative } \\
\text { situations. }\end{array}$ & $\begin{array}{l}\text { Witnessing to } \\
\text { death }\end{array}$ & To witness death in the process. \\
\hline Spirituality & $\begin{array}{l}\text { Interpreting the events without using } \\
\text { the five senses. }\end{array}$ & $\begin{array}{l}\text { Interruption of } \\
\text { education }\end{array}$ & Interruption of education. \\
\hline $\begin{array}{l}\text { Financial } \\
\text { situation }\end{array}$ & Being in a good financial situation & $\begin{array}{l}\text { Social prejudice } \\
\text { and unsupportive }\end{array}$ & $\begin{array}{l}\text { To be excluded by the members of the } \\
\text { host community. }\end{array}$ \\
\hline $\begin{array}{l}\text { Host society } \\
\text { support }\end{array}$ & $\begin{array}{l}\text { Support provided by the residents of } \\
\text { the country. }\end{array}$ & New settlement & $\begin{array}{l}\text { Difficulties in adapting to new rules } \\
\text { and regulations. }\end{array}$ \\
\hline $\begin{array}{l}\text { Immigrant } \\
\text { support }\end{array}$ & $\begin{array}{l}\text { Support from immigrant communities } \\
\text { that have already settled in the } \\
\text { country. }\end{array}$ & Language problem & $\begin{array}{l}\text { Not knowing the language that the } \\
\text { immigrated society is using. }\end{array}$ \\
\hline \multirow[t]{3}{*}{$\begin{array}{l}\text { Family } \\
\text { members } \\
\text { support }\end{array}$} & $\begin{array}{l}\text { Financial and moral support provided } \\
\text { by family members (even if they are } \\
\text { physically distant). }\end{array}$ & $\begin{array}{l}\text { Change of living } \\
\text { space }\end{array}$ & $\begin{array}{l}\text { Moving to new places frequently after } \\
\text { the migration process. }\end{array}$ \\
\hline & & $\begin{array}{l}\text { Death of family } \\
\text { member }\end{array}$ & Losing someone in the family. \\
\hline & & Living apart & $\begin{array}{l}\text { Family members living in different } \\
\text { cities. }\end{array}$ \\
\hline
\end{tabular}

The interviews with the participants were recorded with the voice recorder with the permission of the participants. Recorded interviews were transferred to the computer without data loss. Transferred data was analyzed with content analysis by MAXQDA 12, a computer-assisted qualitative data analysis program. Content analysis reveals the hidden facts with identification of data and the gathering data together within the framework of similar themes (Yıldırım \& Şimşek, 2013).

The measurement instruments used in the research and the details of the research (sample, method, etc.) have been reviewed and approved by Hasan Kalyoncu University Ethics Committee.

\section{FINDINGS}

\section{Distribution of Risk Factors}

The classification of the risks which individuals have as a result of the interviews is shown in Figure 1. According to Figure 1, participants were exposed to social risk factors more. It is followed by familial and individual risk factors. 


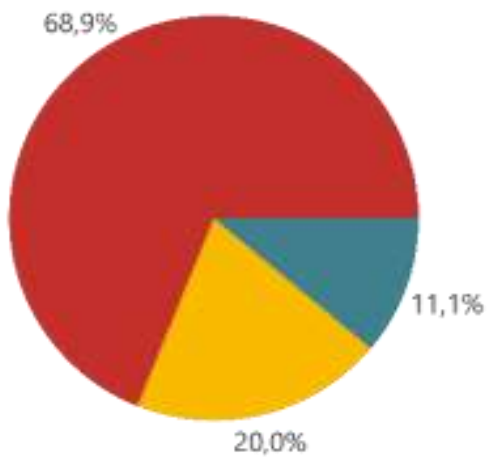

Figure 1. Distribution of Risk Factors

\section{Resources of Risk Factors}

The risk factors of the participants are shown in Figure 2 according to individual, familial and social resources, number of people and intensity of experience. Accordingly, mistrust in others, negative perspective on life and difficulty in anger control are the individual risks that participants have. When the intensity of the individual risks within itself is taken into consideration, it is seen that the negative perspective on life and anger control are more intense than the rest.

The familial risk factors that participants have are grouped under two main categories. The loss of a family member and the family members' being in different countries and cities are some of the indicated familial risk factors. When the responses are examined, being away from family members is a highly stated familial risk factor.

When the social risk factors of the participants are examined, eight main sources are named: the difficulties experienced by being moved to a new settlement, social prejudice and unsupportive society, interruption of education processes, being forced to witness any death, the negative effect of the media, the constant change of life space, the language problems and financial inadequacies. When the responses of the participants are examined, the language problems they are experiencing because of not knowing Turkish is considered as the biggest social risk factor. The second most important risk factor is social prejudice/ being unsupportive. Not being accepted to the new society and being observed with prejudice are important risk sources for these people. Another important social risk for these people, many of whom lost their financial resources because of the war, is their financial difficulties. Apart from financial difficulties, leaving their country despite studying at a university there or extended duration of transition to university after high school is a significant risk factor for these people. Moreover, constant change of settlement before and after coming to Turkey is another risk factor for the participants. Apart from these, according to the intensity level: adapting the social and cultural environment in Turkey, the news they receive through the social media about the countries they came from and witnessing a death are social risk sources for these people. 


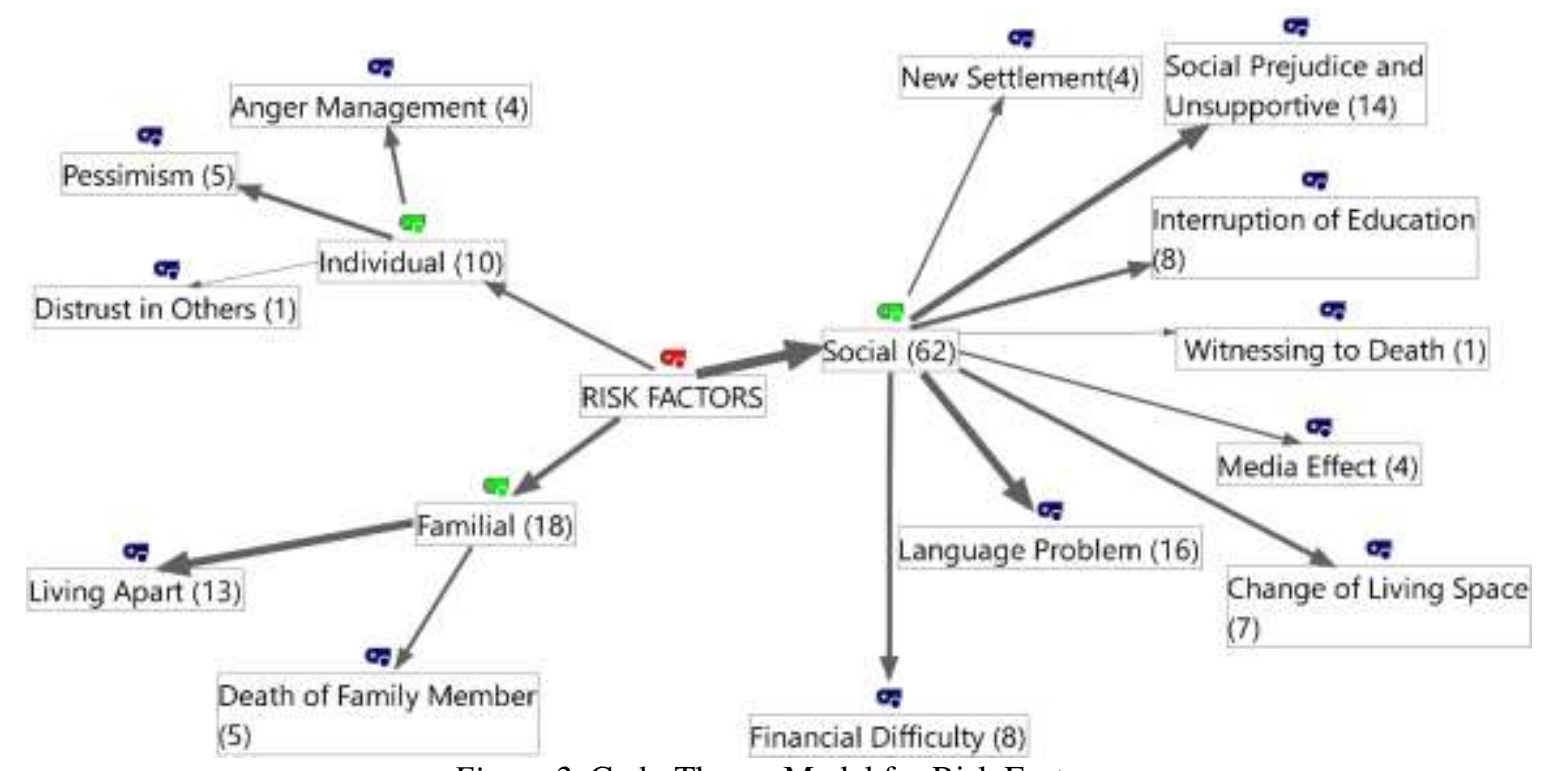

Figure 2. Code-Theory Model for Risk Factors

\section{Distribution of Protective Factors}

The classification of the protective factors of the individuals as a result of the interviews with the participants is given in Figure 3. Thus, it is seen that among the participants the primary protective factor is the individual related factor and has intensity more than half of the protective factors. Individual protective factors are followed by familial and social factors, respectively.
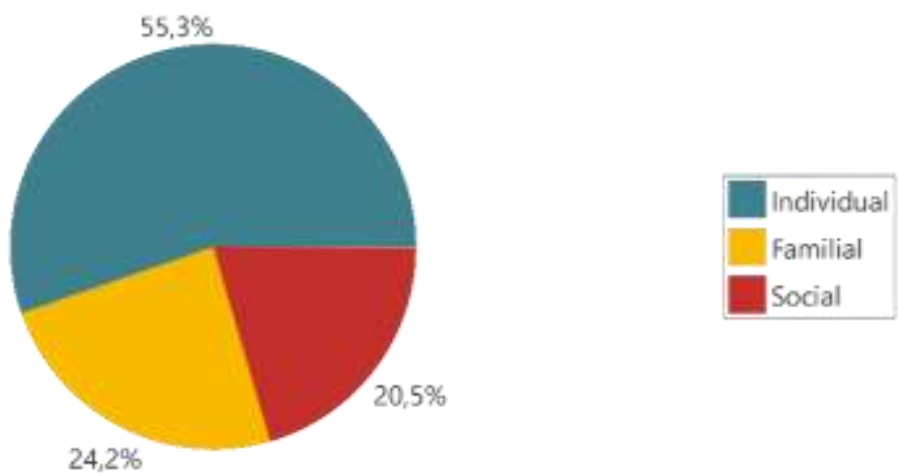

Figure 3. Distribution of Protective Factors

\section{Resources of Protective Factors}

The individual, familial and social resources of the risk factors are shown in the Code-Theory Model in Figure 4. According to this, the social protection factors of the individuals are the social support they receive from the host community, the support they receive from the immigrants like themselves and the effect of financial situation. When the social protective factors are examined according to intensity, it is seen that the support of the host community is the biggest social protective resource for the participants. Furthermore, the support they receive from the immigrants like themselves are also being observed. Although it is only one response, the case of having a good financial situation is also a protective social resource for the participants. 
The emphasis made by the participants for the support of one or more of the family members is presented as intensity in Figure 4. The support of family members is a very important familial protection factor for these people.

The individual protective factors as a result of the interviews with the participants are as follows: determination, desire for learning, self-confidence, spirituality, career goals, patience, desire for social contribution and hope. When the intensity of the responses is investigated, it is seen that the most important individual protective factor for the participants is spirituality. The religious/spiritual beliefs of these individuals are an effective protective factor for resilience. Secondly, the hope of the participants related to life seems to be an important protective factor. Another important individual protective factor is that these people have career goals. Professional and educational goals are important protective factors for these people in becoming resilient individuals. Following the career goals, another important factor is determination. The things people do for the purpose of their goal have been an effective source of their resilience. The desire to constantly learn new things, being patient in the face of the events, desire to contribute to the society they live in and having self-confidence are other individual protective factors, respectively.

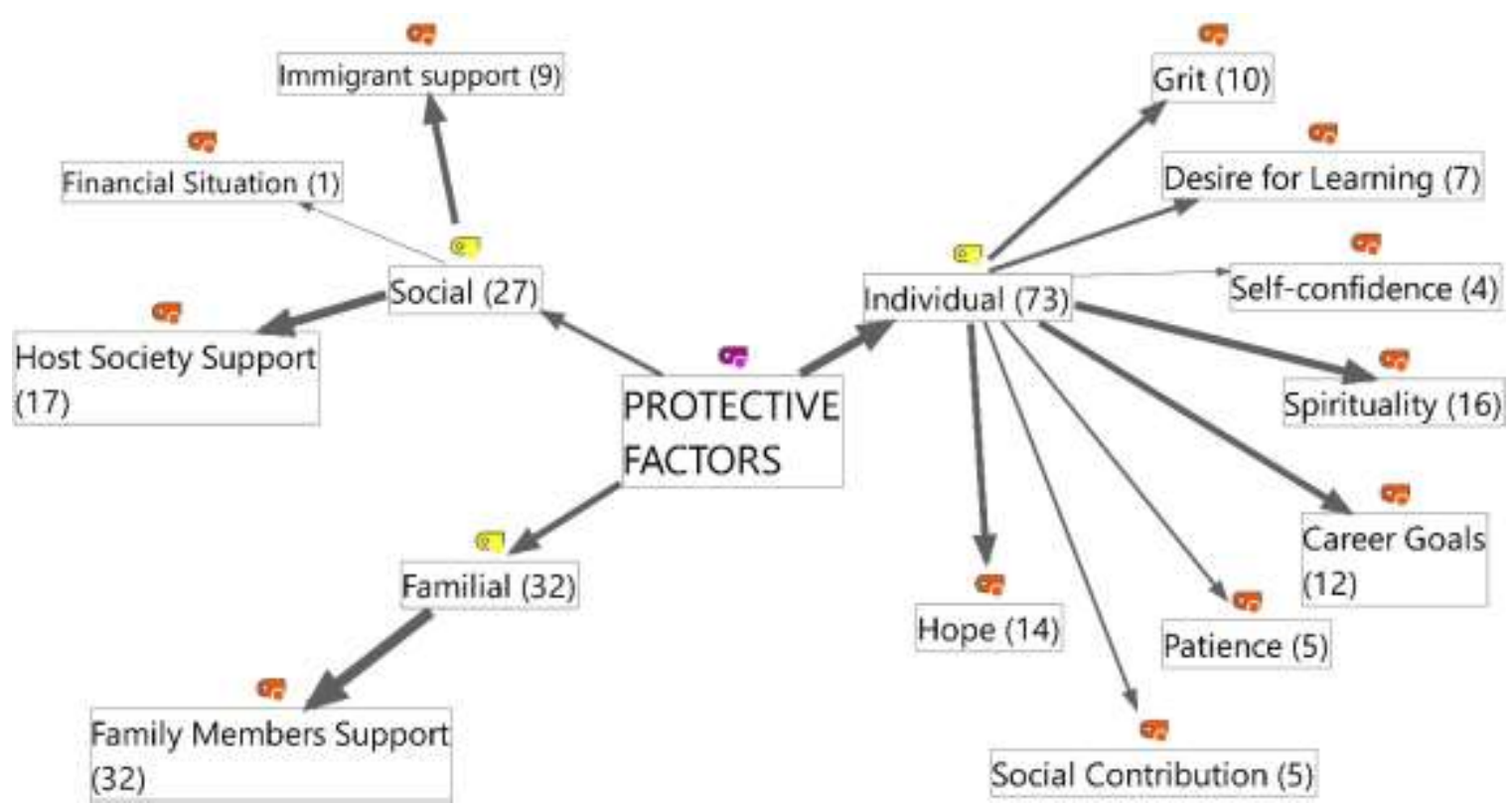

Figure 4. Code-Theory Model for Protective Factors

\section{Being Happy and Strong}

Many of the participants identified themselves as strong and standing after these processes (Figure 5).

M2: 'I feel strong, I have changed a lot of cities and this requires strength.',

F5: 'I am very strong. I am not afraid of anything." 


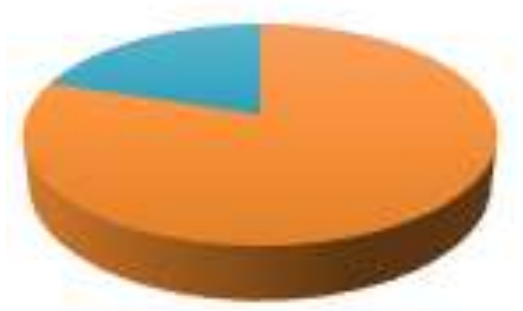

Strong wOther

Figure 5. Rates of Participants Expressing Their Strength

In addition to being strong, participants emphasized that they are happy and content with their current lives despite everything (Figure 6).

M4: ' I am happy because I can buy my bread comfortably; I am with my friends and I can go wherever I want."

F1: 'I'm happy because my family is here."'

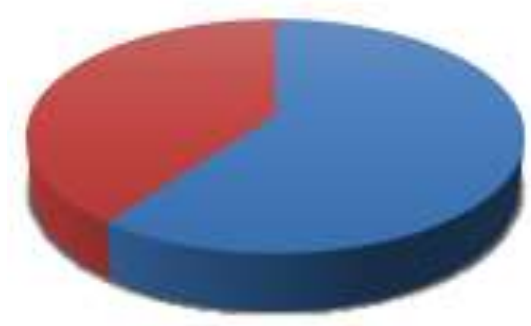

Happy other

Figure 6. Rate of Participants Expressing Their Happiness

When the figures 5 and 6 are examined, it is observed that the ratio of the participants to express themselves as happy and strong, which are the signs of resilience, is high.

\section{Protective and Risk Factors of the Participants}

The distribution of the risk and protective factors of the participants are given in Figure 7 (round shapes in the figures indicate intensity). Accordingly, when the stories of the participants are taken into consideration one by one, the following results emerge:

M1 underlined seven cases from the risk factors. It seems that language is the most intense factor among the risks he has experienced. M1 described the issue as follows: 'Not knowing the language was the biggest problem."

It appears that there are four protective factors for M1 against the risk factors he had experienced. M1 highlighted that the most intensive protective factor among these four was the support of family members. M1 stated this as follows: "my mother was always supporting me". 
M2 emphasized eight cases among the risk factors. For M2, the most intense one among these factors is the constant change of the environment they live in. One of the sentences he used to describe this situation is: "The place where the first war started was where my university was. The state called me to war, and from there I came to my hometown. After that I came to Turkey to study. After a few places in Turkey, I came to Gaziantep."

In addition to these risk factors he experienced, M2 emphasized protective factors in eight cases. Among these protective factors, the most intense one for $\mathrm{M} 2$ is the support of the family members, as in the case with M1. M2 expressed this situation as follows: 'All my family members supported me, especially my brother in Arabia."

When the risk factors in M3's life are examined, risks factors of five areas are observed. Among these risks, the most frequently given answers are social risk factors related to the language problem. One of the sentencesM3 used to express this situation is as follows: "Everyone does not speak English here; I do not speak Turkish. This became very problematic. For example, my brother was sick. He was using a medicine, and stayed in the hospital. I needed to wait two months for a report. How can a patient wait 2 months for a report? We cannot express ourselves clearly. It is difficult for me since I cannot communicate for these."

Besides these risk factors, M3 has seven protective factors, and the most intensive factor is the support of the family members. One of the sentences he used to express this situation is as follows: "I have my parents and I am strong."

The most intensive risk factor that M4 experienced, among four major risk factors, is familial. One of the things M4 said about the risk factors in his life is as follows: "losing my brother and my mother was the greatest difficulty in my life, there were only my brother and my mother and they are no longer here. In difficult times we can hug, kiss, we are family, we can wait our father together, we dine and travel together but they are gone."

In addition to these risk factors that M4 experienced, there are ten protective factors among which support from the host community is the most intense one. One of the phrases he used when expressing this situation is as follows: 'I have a really good friend, he is from Trabzon and he helped me a lot. Last summer I went to Bursa; they have a construction company there. His father said to me 'you are my son as well'. His father is also very good."

Among seven risk factors he had, the risk factor that M5 emphasized most is the financial crisis and interruption of his education process. M5 expressed these situations as follows: 'Sometimes our situation becomes very bad. We could not pay the rent four months ago. I left the university in the second grade."

In addition to the risk factors, the most intensive one among ten protective factors is the support of family members for M5. He said "My father always trusts and supports us. My sister and my brother are also supportive. My mother always says stay away from unlawful things. Thank god they all support me."

For F1, among eight risk factors the most intense one is no support from social environment. F1 expressed this situation as follows: "At first they didn't welcome kindly. They said that we were entering the university easily."

When the protective factors of F1 are examined, it is observed that the same risk factors appear as protective factors. The support given by the host community has become the most intensive protective factor for $\mathrm{F} 1$ in the following periods. One of the phrases that $\mathrm{K} 1$ used to express this situation is as follows: "They all came to me and they helped me. Then we really all became friends in our class slowly.", 
When the risk factors of $\mathrm{F} 2$ are examined, it is found that the lack of social support/prejudice is the most intense one among eight risk factors. One of the phrases that $\mathrm{K} 2$ used to express this situation is as follows: 'I was marginalized in Gaziantep."

When the protective factors of F2 are examined, the most intensive one among seven protective factors are found to be career goals, support of the host community and family members. F2 expressed this situation as follows: "In my life after coming to Turkey I always wanted to open a private school, boarding school I mean. The Turks supported me most. I got support from my husband and my sister."

Among six risk factors that F3 have, the most intensive ones are lack of social support/prejudice and family members separated from each other. F3 explained these situations as follows: "For example, my father, who took me to school every morning, is not here with me now. When somebody misbehaves against me I cannot talk about it. I'm a guest; after all, I cannot say anything. Things I hear from around strains me."

When the protective factors of F3 are examined, it is found that the most intense one among nine protective factors is support of the family members. F3 expressed this situation as follows: "Everybody in the family support each other financially and morally. My father and my mother provide financial support, but spiritually we all support each other."

When the risk factors of $\mathrm{F} 4$ are examined, it is found that language problem and financial difficulties are the most intense ones among eight risk factors. F4 expressed this as follows: "My problem was with the language most. Financial situation forces us most. Such as house rent and bills."

When the protective factors of F4 are investigated, it is found that the most intense one among seven protective factors was spirituality. F4 explained this situation as follows: "God will never abandon us, if we pray."

When the risk factors of F5 are examined, it is found that there are four risk factors and their intensity are all the same. Anger control, social prejudice/lack of social support, living problems related to the new habitat and family members being apart from each other are the risk factors F5 experiencing. F5 expressed these risk factors as follows: "I am so angry."

When six protective factors of F5 are examined, it is found that the most intense one is familial support. F5 expressed this situation as follows: "It makes me feels so good to be with my family." 


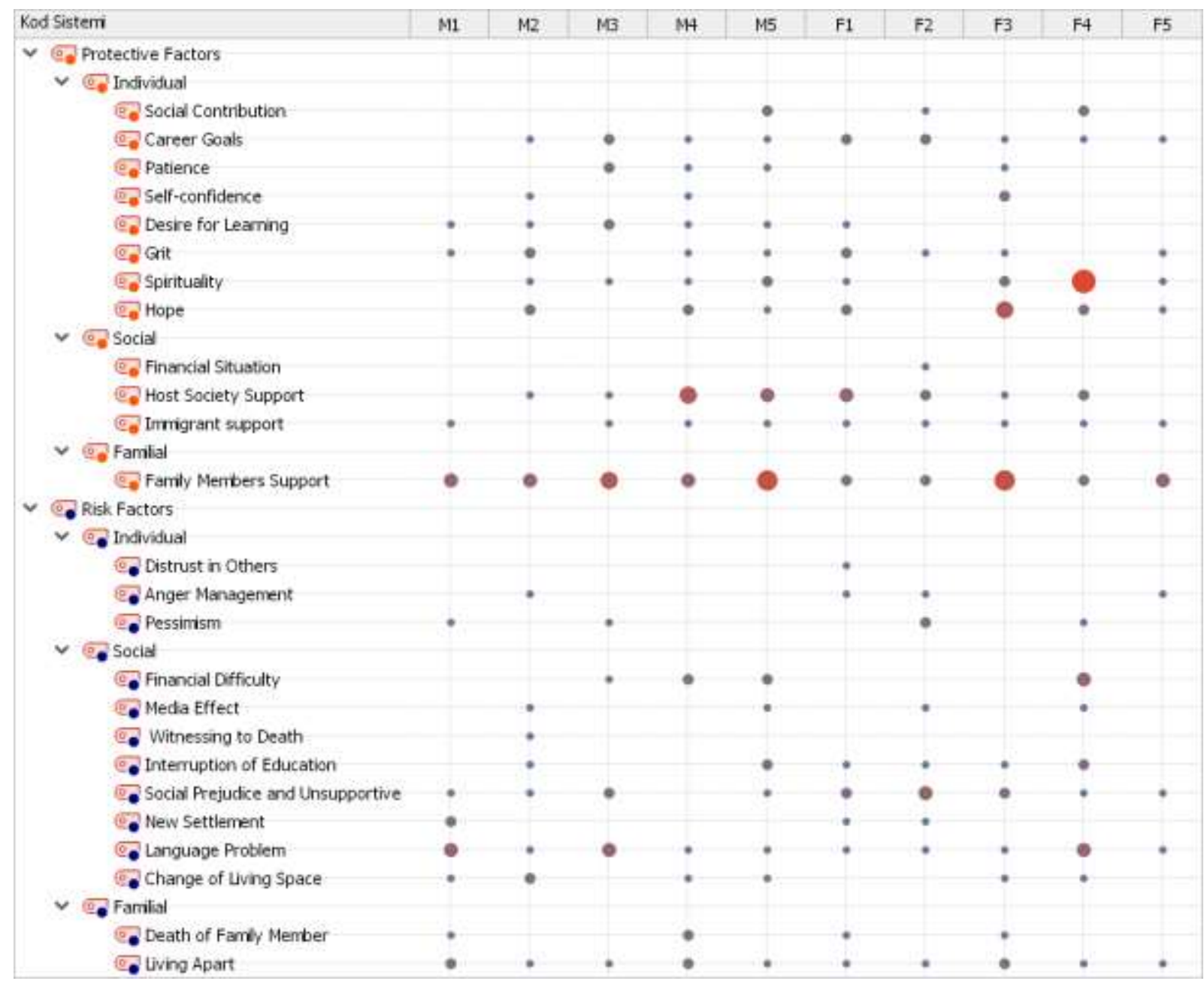

Figure 7. Risk and Protective Factors of Individuals

\section{DISCUSSION}

Immigrants usually cannot choose the place where they settle because of many factors such as economic, social or political factors (Mawani, 2014). The risks are inevitable for immigrants who cannot choose their living space. In a country they do not know at all, the problems that they experience in distinguishing between right and wrong will carry them to new social risks. As Masten (2014) stated, the risks in the living space will always trigger other risks since one risk will bring another. This situation will lead them to experience the existing social risks intensively.

Language-related risks are one of the most intensified risk factors for participants. Language is one of the most important risks that immigrant group experiences (Beiser, Simich, Pandalangat, Nowakowski, \& Tian, 2011; Nwadiora \& Mcadoo, 1996; Stewart, Anderson, Beiser, Makwarimba, Yeh, Kim, Pituc, \& Atkins, 2008; Stewart, Simich, Shiza, Makumbe, \& Makwarimba, 2012). This makes it difficult for them to reach adequate resources (Guerin, Abdi, \& Guerin, 2003). Participants stated that they have difficulty when buying bread from the grocery store, in official documents, in hospitals, on the bus, and in many other occasions where language is used. This has also led them away from the social network, which is a protective factor. 
The existence of social support is vital for the resilience of the immigrant group (Pieloch, McCullough, $\&$ Marks, 2016). However, immigrants often face various prejudices such as ethnocentrisms, racism and economic discrimination (Ellis, MacDonald, Klunk-Gillis, Lincoln, Strunin, \& Cabral, 2010; Yakushko \& Morgan, 2012). Social exclusion of immigrants affects their soul and body health negatively by limiting the opportunities for education, employment, housing and reducing self-esteem (Dunn \& Dyck 2000; Mawani, 2014; Reynolds, 2004). Prejudice and lack of support stated by the participants seem to be the risk factors that immigrants are generally exposed to. This risk factor is of great importance as it also directly affects mental health.

It appears that the reason for the interruption of the participants' education process is due to the destruction of their schools because of the war in the country where they came from. The fact that the war physically destroys the schools is one of the first risk factor for education. As stated earlier, experienced language-related problems and the situation of migration prevent the immediate availability of the education in the process. In addition, it can be said that the frequent change of the living areas, which participants indicated among the risk factors, made it difficult to provide an environment for education.

Immigrants usually have to leave their country without a chance to get money because of the war (Mawani, 2014). This causes changes in their financial situation in the countries where they have newly settled (Bennett, Boshoff, \& Colleen, 1997). Many of the participants have narrated this case by giving examples from their lives. Doctors, a famous journalist, an important farm owner, and the ones whose family is a holding owner became to put together finances to pay the rent after migrating to Turkey. Moreover, immigrants are experiencing employment problems in new countries where they settled (Aycan \& Berry, 1996). Immigrants, who are seen as cheap labor force in the countries where they settle, have to work at very low wages as it is in our country. As supported by research, working with low wages is a serious risk factor for immigrants who have already come to the country without any money (Stewart, et.al. 2012).

Studies on immigrants indicated that individuals often have to leave family members (Bennett, et.al., 1997; Jaranson, Butcher, Halcon, Johnson, Robertson, Savik, Spring, \& Westermeyer, 2004). This may be related to the death of a family member (Wenzel et al., 2007), or to be physically in different geographies (Stewart et al., 2008). As the participants have emphasized, familial risks continue after the process of breaking away from the family. Individuals, who have migrated, worry about the well-being of their loved ones whom they have left behind (Mawani, 2001). The distance and the communication that cannot be established afterwards is an important risk for immigrants (Stewart et al., 2012).

There are many individuals, familial and social protective factors that make the participants become resilient individuals, despite many risks they have experienced. One of the intensively mentioned factor is that they have spirituality, that is, they have religious beliefs. It is clearly stated in the literature that the religious/spiritual tendencies of immigrants are one of the most important protective factors in the resilience process (Alessi, 2016; Greeff \& Human 2004; Stewart et al., 2008; Xu, 2016). When it is considered that the participants come from the cultural background of the Middle East, the effect of religion becomes even more explicable. Spirituality provides an individual protective factor, while at the same time it strengthens the cultural support systems of immigrants in the settled society (Inman et al., 2007). In addition, in recent years there is also increasing evidence that spirituality is an important factor in terms of mental health protection (Collins \& Guruge, 2008). It is expected that individuals with spirituality assign a meaning to the situation that they experience and it helps them to have hope in this world and in the other world (hereafter) that they think exists.

Hope is another important protective factor as indicated by the participants. Research show that a positive perspective on life and the feeling of hope it brings is an important protective factor in ensuring resilience of immigrants (Alessi, 2016; Pieloch et al., 2016). The most significant indicators of hope are the participants' use of similar statements like "I have had the worst situations and I am here, it will be better tomorrow". When the participant profile is considered, some research findings are also important. 
In Stewart et al. (2012) research and as Kumpfer (1999) stated, young immigrants are more hopeful and positive than middle-aged immigrants. One of the reasons for this situation can be the young people's feeling of more responsibility towards their families (Shakya, Guruge, Hynie, Htoo, Akbari, Jandu, Murtaza, Spasevski, Berhane \& Forster, 2014). This responsibility is an indispensable aspect of hope that keeps them standing. The hope, which serves as a protective factor, is also confronted as a demonstration of resilience.

One of the most striking protective factors mentioned by the participants is the emphasis on the career goals of the individual. Within the scope of the research, the most important finding to explore in accordance with the nature of qualitative research (Yıldırım \& Şimşek, 2013) is career orientation. This is because there is no adequate research on immigrants' career processes. However, clearer career studies should be undertaken for immigrants experiencing employment and training problems (Yakushko \& Morgan, 2012). In addition, Maree and Molepo (2006) emphasize that career stories have a very important place in people's development. A recent study has shown that the purpose of a career is an important protective factor in increasing immigrants' resilience (Pieloch et al., 2016).

Another protective factor indicated by participants in the scope of the research is grit. Grit has an important influence on individuals' resilience. It is an expected situation that young immigrants show resilience with grit despite difficulties (Marshall, Butler, Roche, Cumming, \& Taknint, 2016). Alessi (2016), in his research describes immigrant youth as "individuals who are determined at any cost". In another study, Magro (2009) shows that war weary young people are enthusiastic with their hard work and determinant.

Within the scope of the research, the participants referred to two social support systems. The support of the country that they come, that is the host community's support, is on the first place and the support of the immigrant group who are forced to migrate is on the second place. Research shows that social support is important for immigrants' resilience (Alessi, 2016). This is because the provided social support has an important role in reducing loneliness and increasing self-esteem (Bhui, Craig, Mohamud, Warfa, Stansfeld, Thornicroft, Curtis, \& McCrone, 2006; Turner, Lloyd, \& Roszell, 1999). Therefore, for the immigrant who breaks out of his / her family and friends, the support given by the host community is an extremely important protective factor (Simich, Beiser, \& Mawani, 2003). In addition, immigrants are influenced by government policies and political situations in the countries where they settled (Mawani, 2014). This effect has exhibited a positive structure for immigrants in Turkey so far. The current state policy and the similar rituals and daily life of two cultures are some of the factors facilitating the establishment of the support system according to the participants. In addition to the support they receive from the host community, their immigrant groups also have an important protective influence for the participants. Indeed, research shows that individuals who settled in a country as an immigrant have a greater tendency to co-exist with people from their own country, and that this is a source of relief for them (Mawani, 2001; Stewart et al., 2012). This support system is run better in associations and organizations founded by immigrant groups in Turkey.

Another protective factor that participants strongly emphasized is the support that they receive from family members. Within this context, a good bond established with one or more of the family members nearby or in another country is an important contribution to resilience. The negativities in a new country can provide the possibility of strengthening their rapport and ties for families. Thus, the established strong familial support system is of utmost importance for immigrants (Carranza, 2007).

In the context of the research, it is seen that the participants expressed themselves as standing, strong, self-confident and happy. Having self-confidence in immigrants is a protective factor, but at the same time it is an indicator of resilience (Magro, 2009; Stewart, et. al. 2008). It is also known that the young immigrants who constitute the study group also have more indicators of resilience because of their nature (Marshall et al., 2016; Shakya et al., 2014). Furthermore, it is observed that young people described themselves as happy individuals (Kumpfer, 1999). 


\section{CONCLUSIONS}

The results obtained in this study can be summarized as follows: It is found that the participants who migrated to Turkey because of war were exposed to social risk factors more intensively in risk factors within the context of resilience. This is followed by familial and individual risk factors, respectively. When the risk factors of the participants were examined according to their frequencies; the risks associated with language, not being supported socially and being exposed to prejudice, financial difficulties, and interruption of education processes are the social risk factors that are highly mentioned. The fact that family members are separated from each other is the most common risk factor for familial risk factors, whereas having a negative perspective is the most frequently expressed individual risk factor. Among the protective factors of the participants, it is observed that they have individual factors more. This is followed by familial and social risk factors, respectively. When the protective factors of the participants were examined according to their frequency; having spirituality, career goals, hope, and grit are the most highly expressed individual protective factors. Host society support and immigrant support have been extensively expressed as social protective factors that provide social support. Support from family members is a familial protective factor, which is mentioned by the participants as one of the most important sources. Also, as a sign of resilience of the participants, they have identified themselves mostly as happy, strong and standing.

\section{Suggestions}

Based on the results of the research, it can be suggested that immigrants should be concentrated on career services; social support areas for immigrant students should be established and immigrants should be supported by mentor Turkish families. In terms of method, it can be suggested to use different data collection methods by data triangulation.

\section{Acknowledgement}

This study has been produced from the master's thesis of the first author supervised by the second author and some findings of this paper was presented at the $20^{\text {th }}$ International Congress on Psychological Counseling and Guidance in Samsun (Turkey), 25-27 October, 2018.

\section{REFERENCES}

Alessi, E. J. (2016). Resilience in sexual and gender minority forced migrants: A qualitative exploration. Traumatology, 22(3), 203-213. http://dx.doi.org/10.1037/trm0000077

Aycan, Z., \& Berry, J.W. (1996). Impact of employment-related experiences on immigrants' psychological wellbeing and adaptation to Canada. Canadian Journal of Behavioural Science/Revue canadienne des sciences du comportement, 28(3), 240-251. http://dx.doi.org/10.1037/0008-400X.28.3.240

Beiser, M., Simich, L., Pandalangat, N., Nowakowski, M., \& Tian, F. (2011). Stresses of passage, balms of resettlement, and posttraumatic stress disorder among Sri Lankan Tamils in Canada. The Canadian Journal of Psychiatry, 56(6), 333-340.

Bennett, H., Boshoff, A., \& Rigby, C. (1997). The relationship between tenure, stress and coping strategies of South African immigrants to New Zealand. South African Journal of Psychology, 27(3), 160-165.

Bhui, K., Craig, T., Mohamud, S., Warfa, N., Stansfeld, S.A., Thornicroft, G., Curtis, S., \& McCrone, P. (2006). Mental disorders among Somali refugees. Social Psychiatry and Psychiatric Epidemiology, 41(5), 400-408.

Büyüköztürk, Ş., Kılıç Çakmak, E., Akgün, Ö. E., Karadeniz, Ş. \& Demirel, F. (2016). Bilimsel Araştırma Yöntemleri. Ankara: AnıYayınc1lık. 
Carranza, M. E. (2007). Building resilience and resistance against racism and discrimination among Salvadorian female youth in Canada. Child \& Family Social Work, 12(4), 390-398.

Collins, E. M., \& Guruge, S. (2008). Theoretical perspectives and conceptual frameworks. In S. Guruge \& E. M. Collins (Eds.), Toronto: Centre for Addiction and Mental Health.

Christensen, L. B., Johnson, R. B., \& Turner, L. A. (2014). Research methods design and analysis. Edinburgh: Pearson Education.

Çelik, S. (2014). Nitel analizin kalitesinin ve inanırlığının arttırılması. Bütün, M. ve Demir, S. B. (Ed.), Nitel araştırma ve değerlendirme yöntemleri. Ankara: Pegem.

Demir, (2017). Suriyeli göçmen üniversite öğrencilerinde yılmazlığın incelenmesi (Unpublished Master Thesis). Hasan Kalyoncu University, Gaziantep.

Dunn, J. R., \& Dyck, I. (2000). Social determinants of health in Canada's immigrant population: results from the National Population Health Survey. Social science \& medicine, 51(11), 1573-1593.

Ellis, B. H., MacDonald, H. Z., Klunk Gillis, J., Lincoln, A., Strunin, L., \& Cabral, H. J. (2010). Discrimination and mental health among Somali refugee adolescents: the role of acculturation and gender. American Journal of Orthopsychiatry, 80(4).

Fazel, M., Wheeler, J., \& Danesh, J. (2005). Prevalence of serious mental disorder in 7000 refugees resettled in western countries: a systematic review. The Lancet, 365(9467), 1309-1314.

Fraenkel, J. R., Wallen, N. E., \& Hyun, H. H. (2012). How to design and evaluate research ineducation (8th ed.). New York: Mc GrawHIll.

Gibbs, G. R. (2007). Thematic Coding and Categorizing, Analyzing Qualitative Data. SAGE Publications Ltd., London. http://dx.doi.org/10.4135/9781849208574

Gordon, E. W., \& Song, L. D. (1994). Variations in the experience of resilience. In M. C. Wang \& E. W. Gordon (Eds.), Educational resilience in inner-city America: Challenges and prospects (pp. 27-43). Hillsdale, NJ, US: Lawrence Erlbaum Associates, Inc.

Greeff, A. P., \& Human, B. (2004). Resilience in families in which a parent has died. The American Journal of Family Therapy, 32(1), 27-42.

Guerin, B., Abdi, A., \& Guerin, P. B. (2003). Experiences with the medical and health systems of Somali refugees living in Hamilton. New Zealand Journal of Psychology, 32, 27-32.

Gürcanlı, Z. (2012, 30 Kasım). Suriyeliye ikamet izni. Hürriyet. Erişim adresi: http://www.hurriyet.com.tr/suriyeliye-ikamet-izni-22043791.

Gürgan, U. (2006). Grupla psikolojik danışmanın üniversite öğrencilerinin yılmazlık düzeylerine etkisi. (Unpublished doctoral dissertation). Ankara University, Ankara.

Inman, A. G., Howard, E. E., Beaumont, R. L., \& Walker, J. A. (2007). Cultural transmission: Influence of contextual factors in asian indian immigrant parents' experiences. Journal of Counseling Psychology, 54(1), 93-100. http://dx.doi.org/10.1037/0022-0167.54.1.93

İlbay, N. (2017). Hatay'daki Suriyeli mültecilerin sosyalyaşama adaptasyonu: Sorunlar ve çözüm önerileri (Unpublished doctoral dissertation). Mustafa Kemal University, Hatay.

Jaranson, J. M., Butcher, J., Halcon, L., Johnson, D. R., Robertson, C., Savik, K., Spring, M., \& Westermeyer, J. (2004). Somali and Oromo refugees: correlates of torture and trauma history. American Journal of Public Health, 94(4), 591-598.

Keklik, A. Z. (2016). Suriyeli sığınmacılarda hepatit B ve C hastalık sıklı̆̆ ile bu hastalıklarla ilgili bilgi ve riskli davranış düzeyleri (Unpublished doctoral dissertation). Harran University, Urfa.

Kiernan, K. E., \& Mensah, F. K. (2011). Poverty, family resources and children's early educational attainment: the mediating role of parenting. British Educational Research Journal, 37(2), 317-336.

Kumpfer, K. L. (1999). Factors and processes contributing to resilience: the resilience framework. In M. D. Glantz J. L. Johnson, (Eds), Resilience and development: Positive life adaptations (pp. 179-224). New York: Kluwer Academic/Plenum Publishers.

Magro, K. (2009). Expanding conceptions of intelligence: Lessons learned from refugees and newcomers to Canada. Gifted and Talented International, 24(1), 79-92.

Maree, K., \& Molepo, M. (2006). The use of narratives in cross-cultural career counselling. In M. Macmahon \& W. Patton (Ed.). Career Counselling. Routledge: New York

Marshall, E. A., Butler, K., Roche, T., Cumming, J., \& Taknint, J. T. (2016). Refugee youth: A review of mental health counselling issues and practices. Canadian Psychology/Psychologie canadienne, 57(4), 308-319. http://dx.doi.org/10.1037/cap0000068

Masten, A. S. (2014). Ordinary magic: Resilience in development. New York: The Gullford Press.

Masten, A. S., \& Reed, M. J. (2002). Resilience in development. In C. R. Snyder \& S. J. Lopez (Ed.). The Hadbook of Positive Psychology. Oxford: Oxfort University Pres.

Mawani, F. N. (2001). Sharing attachment across cultures: Learning from immigrants and refugees. Ottawa: Health Canada. 
Mawani, F. N. (2014). Social determinants of refugee mental health. In L. Smitch and L. Andermann (Ed). Refuge and resilience (27-51). New York: Springer.

Nwadiora, E., \& McAdoo, H. (1996). Acculturative stress among Amerasian refugees: Gender and racial differences. Adolescence, 31(122), 477-488.

Öğ̈̈lmüş, S. (2001). Bir kişilik özelliği olarak yılmazlık. I. Ulusal Çocuk ve Suç Sempozyumu: Nedenler ve Önleme Çalışmaları, Ankara (29-30 Mart).

Pickren, W. E. (2014). What is resilience and how does it relate to the refugee experience? Historical and theoretical perspectives. In L. Simich \& L. Andermann (Eds.), International perspectives on migration: Vol. 7. Refuge and resilience: Promoting resilience and mental health among resettled refugees and forced migrants (pp. 7-26). New York, NY, US: Springer Science + Business Media. http://dx.doi.org/10.1007/978-94-007-7923-5_2

Pieloch, K. A., McCullough, M. B., \& Marks, A. K. (2016). Resilience of children with refugee statuses: A research review. Canadian Psychology/Psychologie canadienne, 57(4), 330-339. http://dx.doi.org/10.1037/cap0000073

Reynolds, R.R. (2004). "We Are Not Surviving; We Are Managing": the constitution of a Nigerian diaspora along the contours of the global economy. City \& Society, 16(1), 15-37.

Rutter, M. (1999). Resilience concepts and findings: implications for family therapy. Journal of Family Therapy, 21(2), 119-144.

Seligman, M.E., \& Csikszentmihalyi, M. (2014). Positive psychology: An introduction. Springer Netherlands.

Shakya, Y.B., Guruge, S., Hynie, M., Htoo, S., Akbari, A., Jandu, B.B., Murtaza, R., Spasevski, M., Berhane, N., \& Forster, J. (2014). Refugee youth as "resettlement champions" for their families: Resilience, empowerment and vulnerabilities. In Laura Simich \& Lisa Anderman (Eds.), Refuge and resilience (pp.131-154). New York: Springer.

Simich, L., Beiser, M., \& Mawani, F.N. (2003). Social support and the significance of shared experience in refugee migration and resettlement. Western Journal of Nursing Research, 25(7), 872-891.

Sipahioğlu, Ö. (2008). Farklı risk gruplarındaki ergenlerin psikolojik sağlamlıklarının incelenmesi (Unpublished Master Thesis). Selcuk University, Konya.

Stewart, M., Anderson, J., Beiser, M., Mwakarimba, E., Neufeld, A., Simich, L., \& Spitzer, D. (2008). Multicultural meanings of social support among immigrants and refugees. International Migration, 46(3), 123-159.

Stewart, M., Simich, L., Shizha, E., Makumbe, K., \& Makwarimba, E. (2012). Supporting African refugees in Canada: insights from a support intervention. Health \& social care in the community, 20(5), 516-527.

Terzi, Ş. (2008). Üniversite Öğrencilerinde Kendini Toparlama Gücünün İçsel Koruyucu Faktörlerle İlişkisi. Hacettepe Üniversitesi Ĕgitim Fakültesi Dergisi, 297-306.

Turner, R.J., Lloyd, D.A., \& Roszell, P. (1999). Personal resources and the social distribution of depression. American journal of community psychology, 27(5), 643-672.

Unat, D. B. (2015). Türkiye'de yaşayan Suriyeli göçmenlerin gündelik yaşam pratikleri: Mardin örneği (Unpublished Master Thesis). Mugla Sitki Kocman University, Mugla.

Wenzel, T., Kastrup, M., \& Eisenman, D. (2007). Survivors of torture: A hidden population. In P. Walker \& E. Barnett (Eds.), Immigrant medicine. Philadelphia: Saunders.

Xu, Q. (2017). How resilient a refugee community could be: The Vietnamese of New Orleans. Traumatology, 23(1), 56-67. http://dx.doi.org/10.1037/trm0000091.

Yakushko, O., \& Morgan M.L. (2012). Immigration. In R. A. Young, J. F. Domeneve L. Valach (Ed.). Counseling and Action. New York: Springer.

Yeh, C. J., Kim, A. B., Pituc, S. T., \& Atkins, M. (2008). Poverty, loss, and resilience: The story of Chinese immigrant youth. Journal of Counseling Psychology, 55(1), 34-48. http://dx.doi.org/10.1037/00220167.55.1.34

Yıldırım, A., \& Şimşek, H. (2013). Sosyal bilimlerde nitel araştırma yöntemleri. Ankara: Seçkin Yayıncılık. 


\section{TÜRKÇE GENIŞLETILMIŞ ÖZET}

Göçmenler, yaşamak zorunda kaldıkları durumlardan dolayı bazı risk faktörlerine maruz kalmaya daha açıktırlar ve içinde bulundukları topluma oranla daha fazla travma sonrası stres bozukluğuna maruz kalmaktadırlar. Kendi ülkelerinde birçok travmatik olaya maruz kalan göçmenler, yerleştikleri ülkelerde ise genellikle yeni yerleşim yerine uyum ile ilgili süreçlerde zorluk çekerler. UNHCR (Birleşmiş Milletler Mülteciler Yüksek Komiserliği Bürosu'nun) ve birçok araştırmacı savaştan dolayı göç etmek zorunda kalmış olan göçmenlerin diğer göç eden bireylere göre daha farklı deneyimler yaşadı̆̆ını göstermektedir. Çoğu savaş mağduru göçmenler uzun süreli silahlı çatışmalara, şiddete, aile üyelerinin kaybına veya toplu bir şekilde ölümleri izlemeye maruz kalmıştır. Göç eden kişilerin yerleştikleri ülkelerdeki en önemli sosyal faktörler sosyal içerme/dışlanma ve resmi sosyal destektir. Ancak çok az araştırma sosyal dışlanma konusunu vurgulamaktadır. Bu durum yaş, cinsiyet, rrk, etnik köken, sosyal sınıf, göç durumu, cinsel yönelim gibi durumlardan kaynaklanabilmektedir. Göçmenler, tüm bu faktörlere dayalı olarak bireysel veya sistemsel (kurumsal) düzeyde dışlanma riski altındadır. Sosyal dışlanma; eğitim, istihdam, konut vb. fırsatları sınırlandırarak benlik saygısını düşürmekte ve ruh sağlığını olumsuz bir biçimde etkilemektedir. Yaşanılan bu tür risklere rağmen göçmenlerin bu süreçlerde, nasıl yılmadan ayakta durdukları ve nasıl baş ettikleriyle, dolayısıyla nasıl yılmaz bireyler olabileceği ile ilgili daha fazla bilgiye ihtiyaç vardır. Bu nedenlerden dolayı araştırma kapsamında savaş mağduru göçmenlerin yılmazlık kaynakları incelenmiştir. Araştırmanın amacı Suriyeli göçmen üniversite öğrencilerinde risk ve koruyucu faktörler temelinde yılmazlık kaynaklarını derinlemesine incelemektir. Bu kapsamda; Suriyeli göçmen üniversite öğrencilerinin hangi risk faktörlerine, hangi koruyucu faktörlere ve bunların yanında yılmazlık sonucu olarak hangi göstergelere sahip oldukları araştırılmıştır.

Son yıllarda çeşitli bölgelerde yaşanan savaş ve terör olayları birçok insanın hayatında önemli değişikliklere neden olmuştur. Savaştan dolayı insanlar evlerini, arkadaşlarını, okullarını, ailelerini bırakmak zorunda kalmışlardır. Birçok insan çareyi kendi ülkelerini terk ederek başka ülkelere sığınmakta bulmuştur. Böylece kendi ruh ve beden sağlıklarını koruyarak kalan aile üyelerine yardımcı olabilecek yapıyı oluşturmaya çalışmışlardır. İnsanların kendilerini ve yakınlarını korumak için çıktıkları bu yol, beraberinde tarihin en önemli göç dalgalarından birini oluşturmuştur. Dünya'nın tamamının etkilendiği bu durumdan en çok etkilenen ülkelerden birisi de coğrafi konumundan dolayı Türkiye'dir. Bu kişilere verilecek olan temel yardımların yanı sıra ruh sağlığı hizmeti de bir zorunluluktur. Çünkü göç sonrasında bireylerde çok önemli ruh sağlığı sorunları yaşanmaktadır. Dünyanın birçok farklı yerinden, farklı ev sahibi ülkelere giden göçmenlerin yaşadıkları süreç birbirinden çok farklıdır. Bu sebeple derinlemesine yapılan nitel analizler sürecin daha net bir biçimde ortaya çıkmasına katkıda bulunacaktır. Özellikle Türkiye'de göçmen sayısının fazla olması ve bu göçmenlerin eğitim sistemine uyum sürecine ilişkin algıları ve yaşadıkları zorluklara ışı tutacak olması araştırmanın önemini ve güncelliğini göstermektedir.

Araştırma kapsamında nitel araştırmaların bir türü olan "olgubilim (fenomenoloji) çalışması" kullanılmıştır. Olgubilim çalışması, bize tümüyle yabancı olmayan ancak tam olarak kavrayamadığımız olguların derinlemesine ve ayrıntılı bir biçimde incelenmesidir. Araştırmanın çalışma grubu Türkiye'ye kendi ülkelerindeki savaştan dolayı göç etmiş 21-28 yaş aralığındaki genç göçmenden oluşmaktadır. Nitel araştırmalarda örneklemin büyüklüğ̈̈ verilerin doyum noktasına ulaşması ile ilgilidir. Doyum noktasına ulaşıldıktan sonra bilgiler tekrar edeceğinden yeni veriye ihtiyaç duyulmamaktadır. Bu kapsamda araştırmaya katılan 5 kadın, 5 erkek birey olmak üzere toplamda 10 kişi ile veriler doyum noktasına ulaşmış ve bu kişiler araştırmanın çalışma grubunu oluşturmuştur. Katılımcıların yaş aralığı 21 ve 28 arasında değişmektedir. Türkiye'de bulunma sürelerine bakıldığında katılımcıların en az 2.5 y1l boyunca burada yaşadıkları (ortalama 4.1 yıl) gözlemlenmektedir. Öğrenciler; mimarlık, sağlık bilimleri ve mühendislik fakültelerinde öğrenimlerine devam etmektedirler. Katılımcıların Türkiye’ye göç etmek zorunda kalmadan önceki eğitim durumları incelendiğinde altı katılımcının üniversitelerini 
bırakmak zorunda kaldıkları, diğerlerinin ise liseden sonra üniversite yaşantısını Türkiye'de devam ettirdikleri görülmektedir. Araştırmacı tarafından geliştirilen yarı yapılandırılmış "Göçmen Üniversite Öğrencilerinde Yılmazlık Görüşme Formu" veri toplama aracı olarak kullanılmıştır. Katılımcılar ile yapılan görüşmeler, katılımcıların izinleri dahilinde sadece bu araştırma kapsamında kullanılmak üzere ses kayıt cihazı ile kayıt altına alınmıştır. Kaydedilen görüşmeler, veri kaybı olmadan bilgisayar ortamına (Word Office) aktarılmıştır. Aktarılan bu verilerde bilgisayar destekli bir nitel veri analizi programı olan MAXQDA 12 ile içerik analizi yapılmıştır. İçerik analizi, verilerin tanımlanmasıyla birlikte saklı olan gerçeklerin ortaya çıkarılması ve verilerin birbirine benzeyen temalar çerçevesinde bir araya getirilmesidir. Yapılan içerik analizi sonuçlarına göre katılımcıların risk faktörlerinin daha yoğun olarak toplumsal olduğu görülürken, koruyucu faktörler daha yoğun olarak bireysel yapıya sahiptir. Ayrıca beliritlen risk faktörleri şu şekildedir: Başkalarına güvensizlik, öfke kontrolü, olumsuz bakış açısı, finansal zorluklar, medya etkisi, ölüme şahit olmak, eğitimin sekteye uğraması, sosyal önyargı ve dışlanma, yeni yerleşim yeri ile ilgili sorunlar, dil problemi, yaşam alanı değişimi, aile üyelerinden birinin ölümü ve aile üyelerinden ayrı yaşamak. Koruyucu faktörler ise şu şekildedir: Sosyal destek, kariyer amaçlı1ığı, sabır, özgüven, öğrenmeye istekli olmak, azim, maneviyat, finansal destek, ev sahibi topum desteği, göçmen desteği ve aile üyelerinin desteği. Ayrıca katılımcıların yılmazlığın bir göstergesi olarak, kendilerini mutlu ve ayakta kalmış/güçlü olarak nitelendirme yoğunluklarının fazla olduğu belirlenmiştir. Araştırma sonuçlarından yola çıkarak; göçmenlerde kariyer hizmetlerine yoğunlaşılması, göçmen öğrencilere sosyal destek alanları oluşturulması ve göçmenlere mentör Türk aileler tarafindan destek verilmesi önerilerinde bulunulabilir. 